\title{
Deteksi Toxoplasma gondii dari Sampel Urin dengan Realtime Polymerase Chain Reaction
}

\author{
Fitriana $^{1^{*}}$ \\ ${ }^{1}$ Puslitbang Sumber Daya dan Pelayanan Kesehatan, Balitbangkes, Kemenkes \\ * Correspondence author: fitri.litbang@gmail.com ; Tel.: 081574597570 \\ Received: 9 Februari 2021; Accepted: 8 Maret 2021; Published: 10 Maret 2021
}

\begin{abstract}
Abstrak
Toxoplasma gondii dapat menyebabkan penyakit toksoplasmosis pada manusia. Seropositif yang tidak diobati dapat berkembang menjadi Toksoplasma ensefalitis (sekitar 25\%), kerusakan permanen dan kematian. Pengambilan spesimen secara invasif sebagai salah satu kegagalan pengobatan. Hasil uji serologi tidak mudah di interpretasikan pada pasien imunodefisiensi. janin dan bayi. Realtime PCR sebagai metode pilihan untuk menegakkan diagnosis secara tepat dan cepat. Penelitian ini bertujuan mendeteksi $T$. gondii dengan metode Realtime Polymerase Chain Reaction (Realtime PCR) dari sampel urin. Desain penelitian adalah potong lintang, menggunakan 30 sampel urin penderita HIV/AIDS. DNA di ekstraksi dengan Q1Aamp DNA mini Kit. Realtime PCR Toksoplasma menggunakan enzim RT-PCR Taqman Kit (Bio-Rad). Hasil penelitian PCR dari sampel urin didapatkan 7 sampel (23,3\%) terdeteksi T.gondii. Kesimpulannya bahwa metode PCR dapat digunakan untuk mendeteksi T.gondii dari sampel urin pada pasien HIV/ AIDS.
\end{abstract}

Kata kunci: HIV/AIDS, Realtime PCR, Toksoplasma, Toxoplasma gondii, Urin

\section{Pendahuluan}

Toksoplasmosis adalah suatu penyakit pada manusia yang disebabkan oleh parasit Toxoplasma gondii yang dapat bersifat akut, kronik dan laten $(1,2)$. Parasit ini merupakan penyebab tersering infeksi oportunistik toksoplasma ensefalitis pada pasien Human Immunodeficiency Virus/ Acquired Immunodeficiency Syndrome (HIV/ AIDS) bila dibandingkan infeksi lain (37). Individu dengan HIV-seropositif $T$. gondii yang tidak terobati mempunyai resiko untuk berkembang menjadi toxoplasma ensefalitis sekitar $25 \%$ (8).

Beberapa faktor yang berperan dalam pengendalian infeksi adalah virulensi mikroorgaisme, tropisme jaringan dan respon imun inang, meliputi respon imun seluler dan humoral. Fase 
takizoit dari parasit ini dapat menyebabkan makrofag menghasilkan Interleukin (IL-12), yang kemudian akan terjadi pengaktifan sel Natural Killer (NK) dan sel $\mathrm{T}\left(\mathrm{CD}^{+}\right.$dan $\left.\mathrm{CD}^{+}\right)$, menghasilkan Interferon-g (IFN-g). Selanjutnya IFN-g dan Tumor Necrosis Factor (TNF) akan bersinergis sebagai mediasi terhadap pembunuhan takizoit (3).

Penderita HIV/ AIDS, penerima transplantasi organ, dan pasien kanker, mempunyai tingkat morbiditas dan mortalitas yang tinggi (2). Kegagalan pengobatan umumnya terjadi karena salah diagnosis baik dari gambaran klinis maupun pemeriksaan laboratorium (9), hal ini perlu menjadi perhatian dalam mencari metode pemeriksaan laboratorium yang bersifat sensitif dan dapat diandalkan. Masalah jenis sampel yang digunakan juga dapat menjadi kendala pada pasien toksoplasma ensefalitis AIDS, karena umumnya jenis sampel yang digunakan adalah biopsi otak dan liquid cerebrospinal (LCS) (2).

Dalam menengakkan diagnosis definitif harus ditemukan adanya parasit, sedangkan untuk diagnosis presumtif umumnya menggunakan uji antibodi positif untuk anti-T.gondii (8-10). Metode serologi biasa digunakan untuk menengakkan diagnosis, tapi pemeriksaan ini mempuyai beberapa kelemahan yaitu salah satunya pada interpretasi hasil pada penderita dengan imunokompromais, janin atau bayi (2). Hal tersebut dapat disebabkan karena pada penderita tersebut sering tidak dapat menunjukkan adanya pembentukan antibodi yang cukup dalam serum sehingga dapat menimbulkan hasil sebagai negatif palsu (1).

Metode pemeriksaan lain yang dapat dilakukan adalah dengan indirect fluorescent-antibody test (IFAT), enzim-linked immunosorbent assay (ELISA), kultur jaringan, dan polymerase chain resction (PCR) (2). Polymerase Chain Reaction (PCR) merupakan pemeriksaan molekuler yang dapat mendeteksi T.gondii pada jaringan otak, cairan serebrospinal (CSS), vitreous dan cairan aqueous mata, cairan bilasan bronkoaveolar, cairan amnion dan darah pada pasien AIDS (11).

Pemeriksaan PCR dengan menggunakan cairan serebrospinal dari beberapa penelitian didapatkan hasil bahwa PCR dapat menggantikan diagnosis definitif dari biopsi otak, dengan tingkat sensitivitas dan spesifisitas yang lebih baik (12-14). Keunggulan lain dari pemeriksaan ini adalah tidak dipengaruhi oleh respon imun, sehingga deteksi dapat dilakukan pada sampel dari pasien imunokompromais dan berbagai fase dari penyakit (15). Beberapa publikasi menjelaskan kelebihan PCR dalam memdiagnosis toksoplasmosis kongenital prenatal atau toksoplasmosis ensefalitis pasien AIDS dengan menggunakan gen P30 atau BI atau segmen ribosomal 18S DNA sebagai target (16). Realtime PCR merupakan metode pilihan yang dapat membantu dalam penegakkan diagnosis secara tepat dan cepat (17-19). 
Melihat masalah yang ada pada jenis sampel yang digunakan dengan pengambilan yang memerlukan tindakan invasif serta metode pemeriksaan yang mempunyai beberapa kelemahan maka dikembangkan suatu metode realtime PCR untuk membantu penengakkan diagnosis toksoplasma dengan menggunakan sampel urin yang relatif mudah untuk didapatkan. Penelitian ini bertujuan untuk melihat hasil pemeriksaan dari realtime PCR dalam mendeteksi T. gondii dari sampel urin pada pasien HIV/ AIDS.

\section{Metode}

Desain penelitian adalah dengan potong lintang, jumlah sampel yang digunakan sebanyak 30 orang yang telah terdiagnosis HIV/ AIDS dan di rawat di rumah sakit (RS) Pengayoman Cipinang Jakarta. Pemeriksaan sampel dilakukan pada Laboratorium Mikrobiologi Klinik (LMK) Fakultas Kedokteran Universitas Indonesia (FKUI), yang berada pada periode bulan Maret sampai Oktober 2016 (20).

Sampel urin yang diambil adalah urin pancar tengah yang diambil pada pagi hari dengan menggunakan pot urin steril. Urin yang sudah diambil dikumpulkan pada suhu -4 'C untuk kemudian di bawa ke LMK FKUI dengan menggunakan coolbox yang telah diisi dengan 6 buah dry ice (20). Di laboratorium tujuan, sampel urin akan dilakukan aliquat, kemudian disimpan pada suhu -80'C sampai seluruh sampel terkumpul, untuk kemudian dilakukan pemeriksaan realtime PCR.

\section{Prosedur realtime PCR}

\section{Ekatraksi DNA Toksoplasma gondii}

DNA diekstraksi menggunakan Q1Aamp DNA minikit (Qiagen), sesuai dengan instruksi manufaktur (21). Volume elusi DNA akhir sebanyak 40 $\mu 1$. Volume sampel yang akan diekstraksi sebanyak $1 \mathrm{ml}$. Prosedur ekstraksi DNA adalah sebagai berikut yaitu sentrifus $1 \mathrm{ml}$ sampel pada $12000 \mathrm{rpm}$ selama 2 menit, kemudian buang supernatant tanpa mengganggu pellet, lalu tambahkan $20 \mu \mathrm{l}$ Qiagen protease (proteinase K) dan tambahkan $180 \mu 1$ Buffer ATL, campur menggunakan pulse-vortex selama 15 detik, dan lisiskan sel dengan di inkubasi pada suhu $56^{\circ} \mathrm{C}$ selama 3 jam. Sentrifus tabung selama 15 detik, lalu tambahkan $200 \mu 1$ Buffer $A L$, dan campur rata dengan menggunakan pulse-vortex selama 5 detik.

Inkubasi tabung pada suhu $70^{\circ} \mathrm{C}$ selama 10 menit, kemudian sentrifus tabung selama

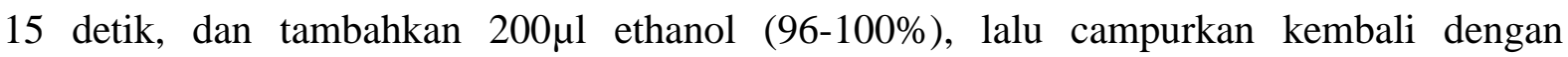
menggunakan pulse-vortex selama 15 detik, setelah itu sentrifus tabung selama 15 detik. 


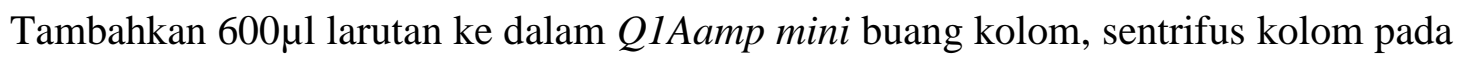
$12000 \mathrm{rpm}$ selama 1 menit, lalu buang tabung yang mengandung filtrate, dan tempatkan Q1Aamp DNA kolom ke dalam $2 \mathrm{ml}$ tabung, kemudian buang yang berisi filtrate dan

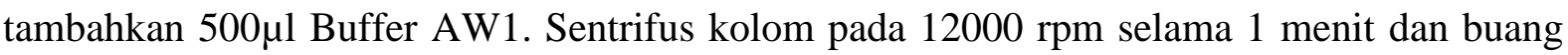
tabung yang mengandung filtrate.

Tempatkan Q1Aamp DNA mini putar kolom ke dalam $2 \mathrm{ml}$ tabung dn tambahkan 500 $\mu \mathrm{l}$ Buffer AW2. Sentrifus kolom pada 12000 rpm selama 1 menit, dengan pipet filtrate dan tempatkan kembali Q1Amp DNA mini putar kolom pada tabung yang sama. Sentrifus tabung kosong pada 12000 rpm selama 2 menit dan tempatkan Q1Amp DNA mini putar kolom pada tabung mikrosenrifus 1,5 ml, kemudian tambahkan $40 \mu \mathrm{l}$ Buffer AE, dan inkubasi pada suhu ruangan selama 5 menit. Sentrifus kolom pada 12000 rpm selama 2 menit, dan terakhir simpan DNA tidak lebih dari 1 minggu sampai nanti akan digunakan pada suhu -20’C.

\section{Real time PCR}

Real time PCR T. gondii menggunakan enzim RT-PCR Taqman Kit (Bio-Rad). Dengan sekuens primer dan probe seperti yang pernah dilaporkan oleh Kompalic tahun $2007 .{ }^{22}$ Untuk primer Forward dengan GENE_B1_TG-TX2F dan sekuens oligonukleotida 5'CTAGTATCGTGCGGCAATGTG3' dan bp 20; primer Reverse GENE_B1_TG-TX2R dan sekuens oligonukleotida adalah 5'GGCAGCGTCTCTTCCTCTTTT3' serta bp 21; Probe dengan GENE_B1_TG-TX2MI dan sekuens oligonukleotida 5'(6-FAM)CCACCTCGCCTCTTGG-(NFQ-MGB)3' dan bp $15 .{ }^{22}$

Campuran reaksi pertama kali diinkubasi pada suhu $50^{\circ} \mathrm{C}$ selama 1 menit, kemudian diikuti tahapan 8 menit pada $95^{\circ} \mathrm{C}$ amplifikasi yang dilakukan dalam 40 siklus denaturasi $\left(95^{\circ} \mathrm{C}\right.$ selama 15 menit; laju lereng, $20^{\circ} \mathrm{C} /$ detik $)$, annealing $\left(60^{\circ} \mathrm{C}\right.$ selama 1 menit dengan laju lereng, $20^{\circ} \mathrm{C} /$ detik), dan ekstensi $\left(72^{\circ} \mathrm{C}\right.$ selama 50 detik, dengan laju lereng $20^{\circ} \mathrm{C} /$ detik).

Hasil dianggap positif bila terdapat sinyal fluoresen yang signifikan diatas baseline yang telah terdeteksi, seperti ditentukan dengan metode algoritma derivatif kedua, dan dinyatakan sebagai nilai siklus kuantifikasi $(\mathrm{Cq})$. Setiap akan dijalankan, terdapat DNA T.gondii sebagai kontrol positif dan penggunaan buffer elusi untuk ekstraksi DNA sebagai kontrol negatif. 


\section{Hasil penelitian}

Dari 30 responden didapatkan sebanyak 7 responden $(23,3 \%)$ mempunyai hasil positif Toxoplasma gondii dari penggunaan sampel urin. ${ }^{20}$

Tabel 1. Hasil realtime PCR Toxoplasma gondii ${ }^{20}$

\begin{tabular}{lcc}
\hline PCR & Frekuensi (n) & Persentase (\%) \\
\hline Positif & 7 & 23,3 \\
Negatif & 23 & 76,7 \\
Total & 30 & 100 \\
\hline
\end{tabular}

\section{Pembahasan}

Metode realtime PCR ini menggunakan suhu annealing pada $60^{\prime} \mathrm{C}$ yang sesuai dengan suhu yang dilakukan oleh Kompalic pada tahun 2007 (22). Penggunaan gen B1 dan gen RE sesuai dengan penelitian yang dilakukan oleh Mesquita dkk yang membandingkan realtime PCR dengan Taqman, dan didapatkan hasil sensitivitas dengan nilai gen B1 sebesar 86\%, dan gen RE dengan nilai sensitivitas sebesar 98\%, sedangkan untuk nilai spesifisitas gen B1 adalah 97\% dan gen RE sebesar 88,8\% (23).

Dari penelitian tersebut, Mesquita dkk mendapatkan hasil realtime PCR dari sampel darah dan cairan serebrospinal pasien HIV yang diduga toksoplasma ensefalitis, dengan gen B1 sebagai gen target, maka didapatkan hasil positif T.gondii dari sampel darah sebesar 34\%, sedangkan dari cairan serebrospinal sebesar 23,91\% (23).

Pada penelitian ini, dengan menggunakan metode realtime PCR dan sampel dari urin, didapatkan hasil sebesar 23,3\% terdeteksi T.gondii, 7 pasien dari 30 pasien yang menjadi sampel, hasil pemeriksaan ini mendekati hasil positif pada cairan serebrospinal yang dilakukan oleh Mesquita dkk. Modifikasi yang dilakukan pada metode realtime PCR berada pada suhu annealing 60 ' $\mathrm{C}$ dan penggunaan gen $\mathrm{B} 1$ dan gen $\mathrm{RE}$.

Selama ini PCR sudah dapat digunakan untuk membantu diagnosis toksoplasma terutama pada pasien imunokompromais, dengan jenis sampel yang diambil dari berbagai cairan tubuh termasuk salah satunya dari urin. Realtime PCR sendiri saat ini juga sudah mulai digunakan untuk membantu diagnosis, dengan memasukan flouresens sebagai label pada probe oligonukleotida, selain itu juga dapat mengurangi resiko terjadinya kontaminasi pada DNA $(24,25)$. 


\section{Kesimpulan}

Realtime PCR yang telah dimodifikasi pada suhu annealing, serta penggunaan gen B1 dan gen RE dapat digunakan untuk mendeteksi Toxoplasma gondii dari sampel urin pasien dengan imunokompromais (HIV/ AIDS).

\section{Daftar Pustaka}

1. Chahaya,I. Epidemiologi Toxoplasma gondii. Kesehatan Lingkungan Falkutas Kesehatan Masyarakat. Universitas Sumatera Utara. 2003.

2. Xin Hu, Chang-Wang Pan, Ya-Fei Li, et.al. Urine Sample Used For Detection Of Toxoplasma Gondii Infection By Loop-Mediated Isothermal Amplification (LAMP). Folia Parasitologica 59 (1):21-26. 2012.

3. G.M. Bhopale. Patogenesis of Toxoplasmosis. Comparative immunology, microbiology and infectious diseases 26. 2003.213-222

4. Wijaya KMI, Infeksi HIV pada penderita tuberculosis, Seminar nasional FMIPA UNDIKSHA III 2013:295-303.

5. Zulkifli Amin et.al. Profil Pasien TB-HIV dan Non TB-HIV di RSCM. Buletin Penelitian Kesehatan, Vol.41, No.4, 2013: 195-199.

6. Lubis AD. Infeksi oportunistik paru pada penderita HIV.Div Peny Inf Tropik. FK USU:116.

7. The International congress on Toxoplasmosis. International jurnal for parasitology 34. 2004. 249-252.

8. Nelson M, Manji H, Wilkins E. Central Nervous System Opportunistic Infections. HIV medicine, 12 (Suppl.2). 2011.

9. Cardona N, Basto N, Parra B, et.al. Detection of Toxoplasma DNA in the Peripheral Blood of HIV-Positive Patients with Neuro-opportunistic Infections by a Real-Time PCR Assay. Journal of Neuroparasitology. Vol. 2. 2011.

10. Vidal JE, Colombo FA, et.al. PCR assay Using Cerebrospinal Fluid for Diagnosis of Cerebral Toxoplasmosis in Brazilian AIDS patients. Journal Clinical Microbiology. P.4765-4768. Vol 42. No 10. 2004.

11. Montoya JG. 2002. Laboratory diagnosis of toxoplasma gondii infection and toxoplasmosis. California: The Journal of Infectious Diseases; Vol 185 Suppl 1: 73 
12. Ammassari A, Cingolani A, Pezzotti P, De Luca A, Murri R, Giancola ML, et al. 2000. Italy: AIDS-related focal brain lesions in the era of Highly Active Antiretroviral Therapy. Neurology. 55:1194-1200

13. Kompalic A, Cristo, Frotta C, Mutis MS, Fernandes O, Britto C. 2007. Evaluation of a real time PCR assay based on the repetitive B1 gene for the detection of Toxoplasma gondii in human peripheral blood. Parasitol Res 101:619-625

14. Nogui NLF, Mattas S, Júnior TG, Lewi SD. 2009. Neurotoxoplasmosis Diagnosis for HIV-1 Patients by Real-Time PCR of Cerebrospinal Fluid. Brazilian Journal of Infectious Diseases 2009;13(1):18-23

15. Maritza PJ, M. Jaime, CE, Maria T, Chang C,Robert . Gilman VH, Martín C, Lopez J, Evans CA. 2002. Optimization and Evaluation of a PCR Assay for Detecting Toxoplasmic Encephalitis in Patients with AIDS. Journal of clinical microbiology. Vol. 40, No. 12: 4499-4503

16. Nguyen T.D, Kesel M.D, Bigaignon G, et.al. Detection of Toxoplasmosis gondii Tachyzoites and Bradyzoites in Blood, Urine, and Brains of Infected Mice. Clinical and diagnostic Laboratory Society for Microbiology. P.635-639. Vol 3. No 6. 1996.

17. Ivovic V, Vujanic M, Živkovic T, Klun I, Djakovic DO. 2012. Molecular Detection and Genotyping of Toxoplasma gondii from Clinical Samples,intech:103-120

18. Vidal JE, Colombo FA, de Oliveira AC, Focaccia R, Pereira-Chioccola VL 2004. PCR assay using cerebrospinal fluid for diagnosis of cerebral toxoplasmosis in Brazilian AIDS patients. J Clin Microbiol 42. 10: 4765-4768

19. Vujanic M . 2012. Molecular detection and genotyping of Toxoplasma gondii strains isolated in Serbia. PhD thesis. University of Belgrade, Serbia

20. Fitriana, Pracoyoo NE. Deteksi Toxoplasma gondii dari Spesimen Urin Penderita HIV/ AIDS. Media Penelitian dan Pengembangan Kesehatan. 2017 vol 27, no 2:105-110

21. Rahmawati E, Imran D, Ibrahim F, Sudarmono P. Deteksi Toxoplasma gondii dan Epstein Barr Virus pada Pasien HIV dengan Infeksi Otak dari Cairan Serebrospinal Dibandingkan dengan Darah Menggunakan Dupleks Real-time PCR. Departemen Mikrobiologi Klinik Fakultas Kedokteran Universitas Indonesia. 2016 (Tesis)

22. Kompalic A, Cristo, Frotta C, et.al. Evaluation of a real time PCR assay based on the repetitive B1 gene for the detection of Toxoplasma gondii in human peripheral blood. Parasitol Res. 2007; 101:619-625 
23. Mesquita RT, Ziegle AP, Hiramoto RM, Vidal JE, Chioccola V. Real time quantitative PCR in cerebral tosxoplasmosis diagnosis of Brazilian human immunodeficiency virusinfected patients. Journal of Medical Microbiology. 2010; 59:641-647

24. Alfonso Y, Fraga J, Fonseca C, Jiménez N, Pinillos T, Contreras JD, et al. Molecular diagnosis of toxoplasma gondii infection in cerebrospinal fluid from AIDS patients. Cerebrospinal Fluid Research; 2009: p 1-6

25. Achappa B, Mahalingam S, Shamir AR, Krishnan BU, Ramapuram JT, Rao S, et al. Clinical spectrum and outcomes for toxoplasma encephalitis among AIDS patients before and during the era of anti-retroviral therapy in Mangalore. India: Journal of Clinical and Diagnostic Research; November 2011; Vol 5 Suppl 2: p 1397-1401. 